\title{
Influence of Hudiara Drain Water Irrigation on Trace Elements Load In Soil And Uptake By Vegetables
}

\author{
MUHAMMAD TARIQ YAMIN; NASIR AHMAD* \\ Post Graduate Center for Earth Sciences, University of the Punjab - Pakistan
}

\begin{abstract}
The rapid urbanization in the cities and increasing load of population generating lot of problems for maintaining environment. The sewage and industrial effluent generated by human settlement are disposed of directly in to nearby rivers / water bodies and agricultural fields. This polluted water not only contains organic matter and crop nutrients but also some toxic metals. The water of these channels may become a potential source of diseases and contaminate our natural resources. In Pakistan it is a common practice to use industrial and sewage effluents for raising crops. Continuous use of such effluent could result in accumulation of metals to such a concentration that may become phytotoxic and eventually hazardous to animal and human health. One such example is the Hudiara drain; a transboundary channel originates from India and enters in Pakistan at village Laloo. Farmers of nearby locality are using the untreated waste water for raising the crops and vegetables. This practice is being done at more than 4000 acres of cultivated area along the Drain by lifting the drain's water through electric pumps, peter engines and tractor driven devices. The density of tubewells is 7 pumps per kilometres for irrigating the farmer's fields and it is increasing day by day. Three points were selected for sampling the vegetables along the $54.6 \mathrm{~km}$ stretch of drain, each at head, middle and tail. Soil samples were taken before sowing and after the harvesting of crops. Plant samples were collected at maturity from all the monitoring points. At each location samples were collected at four nearby sites for detail and representative analysis. During the growing period of crop regular monitoring of Hudiara drain was done for water quality parameters. It was found that metal ions concentration in the vegetables was higher as specified in the standards. Similarly water quality of drain showed increasing level of Residual Sodium Carbonate (RSC), Sodium Adsorption Ratio (SAR) and Electrical Conductivity (EC) as recommended in the water quality criteria. Dissolved Oxygen (DO), Chemical Oxygen Demand (COD) and Biological Oxygen Demand (BOD) requirements of Drain water were also found higher than the National Environmental Quality Standards (NEQS) established under the Pakistan Environmental Protection Act, 1997. It was concluded that continuous use of untreated drain's water is not suitable for raising agricultural crops due to its consequences on human health and soil environment. @JASEM
\end{abstract}

The problem relating to environmental pollution and the need to protect and preserve the environment from further deterioration have largely drawn national as will as people's attention. Industrial pollution is a major problem in our country. The industrial units and factories dump their solid and liquid wastes in spaces adjacent to their sites, sewers, nullahs, and streams or in municipal sewage. These industrial wastes are polluting surface and ground water supplies. The disposal of industrial effluent and discharge of organic and in-organic chemicals, toxic metals, solid wastes both in public and private sector industries of Pakistan, are in violation of factories Act, 1934 and Pakistan Environmental Protection Act, 1997.

The disposal of sewage water is a major problem of big cities. However, the use of untreated sewage water of irrigation in surroundings of urban dwellings for growing crops is a common practice in Pakistan (Ghafoor et al., 1995 \& 1999). The sewage effluents are considered not only a rich source of organic matter and many other plants food nutrients (Ibrahim et al., 1998) but also contain heavy metals like Fe, $\mathrm{Mn}, \mathrm{Cu}, \mathrm{Zn}, \mathrm{Pb}, \mathrm{Cr}$, and $\mathrm{Ni}$. However, continuous use of such effluents for crop production could result in accumulation of such metals in concentrations that may become phytotoxic (Kirkham, 1983; Ghafoor et al., 1999). Eventually accumulation over prolonged time becomes hazardous to animals and human health after entering in their body systems through food chain (Misra and Mani, 1991; Davies and Jones, 1989).

Besides managing the environment to sustain soils and water sources, there is a need to continually increase crop production in a manner that is environmentally sustainable, while providing water to meet new water demands by agriculture, municipalities and industries, as well as minimize energy consumption. Improved irrigation water management practices will not only provide a better agricultural environment, but is essential for sustainable increase in agricultural production, and meeting new water demands.

The environmental problems in our country are, however, too great for the government to tackle alone and to enforce any solution. This endeavor requires the utmost involvement of the people to participate in investigating, restoring and maintaining the environment. One such example is Hadiara drain, which originates in Batala in Gurdaspur district, India and enters Pakistan near village Lalloo. This drain is one of the main tributaries of the river Ravi. The total length of Hudiara drain is $98.6 \mathrm{~km} ; 44.2 \mathrm{~km}$ in Indian territory and $54.4 \mathrm{~km}$ in Pakistani territory. Its annual average discharge at its confluence with the river Ravi is 178 cusecs. There are approximately 120 industries of different natures situated along Hudiara drain in Pakistan, which dump effluent into it. In 
addition, wastewater of some parts of Lahore city and of other small villages also enters this drain.

A number of industries situated on Hadiara drain upto the Ravi confluence, discharge their untreated effluents into it, making it highly polluted and ultimately increasing the pollution load on river Ravi. This drain also receives effluents from Sattokatla drain, East of Lahore having industrial effluents of Kot Lakhpat Industrial Estate. Generally, the growers are not aware of the metal toxicities being introduced into food chain by growing all the kinds of crops with industrial effluent. Industrial effluent in Hadiara drain is used for growing crops and vegetables along its vicinity. The use of food grains, as food for human consumption is becoming questionable. Generally, the growers are not aware of the metal toxicities being introduced into food chain by growing all the kinds of crops with industrial effluent.

Presently, there is a poor scientific research available in Pakistan to show the degree of metal ion contamination in the effluent-applied to soils as well as in the plants grown in these soils. The present investigation was carried out with the objectives.

- To determine the quality of industrial effluents being used for irrigation of crops.

- To determine the concentration of different metal ions in the effluent-irrigated soils and crops.

- Besides managing the environment to sustain soils and water sources, there is a need to continually increase crop production in a manner that is environmentally sustainable.

\section{EXPERIMENTATION}

The effluents being used for irrigation at particular sites were sampled from the channels that supply the effluent to the fields. Samples were collected monthly, at the time of sowing and harvesting of existing crops to analyze the physical and chemical properties at three selected sites (EI ,EII, EIII). Samples were analyzed for electrical conductivity (EC), pH, Sodium Adsorption Ratio (SAR), Residual Sodium Carbonate (RSC). $\left(\mathrm{CO}_{3}\right)$, bicarbonate $\left(\mathrm{HCO}_{3}\right)$, chloride $(\mathrm{CI})$, sulphate $\left(\mathrm{SO}_{4}\right)$, sodium $(\mathrm{Na})$, potassium $(\mathrm{K})$, calcium + magnesium $(\mathrm{Ca}+\mathrm{Mg})$ and calcium $(\mathrm{Ca})$. From some of these parameters RSC and SAR were calculated. The metal ions determined will be $\mathrm{Cr}, \mathrm{Pb}, \mathrm{Zn}$ and $\mathrm{Fe}$.

Soil samples were taken from different depth viz. 015 and 15-30 cm from randomly selected sites' with an auger. These randomly selected samples from each field will be air dried, ground with wooden articles, mixed thoroughly and passed through $2 \mathrm{~mm}$ sieve and stored in labeled plastic bags. These were analyzed for various physical and chemical characteristics listed in Table $1 \mathrm{a}, 1 \mathrm{~b}$ and $1 \mathrm{c}$.

Table 1a. Water quality of city effluent at site EI (village name)

\begin{tabular}{lcccc}
\hline Months & $\begin{array}{c}\text { EC } \\
\left(\mathrm{d} \mathrm{Sm}^{-1}\right)\end{array}$ & $\mathrm{pH}$ & SAR & RSC \\
Nov 02 & 1.6 & 7.3 & 11 & 6 \\
Dec 03 & 1.8 & 7.3 & 12.4 & 6.2 \\
Jan 03 & 1.6 & 7.3 & 8.6 & 5.8 \\
Feb 03 & 1.9 & 7.4 & 10.5 & 5.7 \\
Mar03 & 2.3 & 7.6 & 13.2 & 7.4 \\
Apr 03 & 1.9 & 7.4 & 12.5 & 5.8 \\
May 03 & 2.8 & 7.6 & 15.2 & 9.4 \\
Jun 03 & 3 & 7.6 & 15 & 8.3 \\
July 03 & 1.7 & 7.3 & 10.8 & 5.7 \\
Aug 03 & 1.6 & 7.3 & 11.4 & 5 \\
Sep 03 & 2.2 & 7.4 & 11.5 & 7.5 \\
Oct 03 & 2.1 & 7.4 & 10.8 & 7.5 \\
Mean & 2.0 & 7.4 & 11.9 & 6.7 \\
\hline
\end{tabular}

Table 1b. Water quality of city effluent at site EII (village name)

\begin{tabular}{lcccc}
\hline Month & $\begin{array}{c}\mathrm{EC} \\
\left(\mathrm{d} \mathrm{Sm}^{-1}\right)\end{array}$ & $\mathrm{pH}$ & $\mathrm{SAR}$ & $\mathrm{RSC}$ \\
Nov 02 & 2.4 & 7.4 & 12 & 7.5 \\
Dec 03 & 3.4 & 7.4 & 13.5 & 7.8 \\
Jan 03 & 4.1 & 7.4 & 14.2 & 9.4 \\
Feb 03 & 2.9 & 7.3 & 13 & 7.3 \\
Mar03 & 2.8 & 7.6 & 13.1 & 8.1 \\
Apr 03 & 4.8 & 7.6 & 17.5 & 11.8 \\
May 03 & 5.6 & 7.8 & 16.4 & 13.9 \\
Jun 03 & 4.7 & 7.6 & 16.5 & 9.8 \\
July 03 & 3.8 & 7.5 & 14.2 & 11.2 \\
Aug 03 & 2.7 & 7.5 & 12.3 & 7.5 \\
Sep 03 & 3.1 & 7.5 & 14 & 10.8 \\
Oct 03 & 4.8 & 7.8 & 18.7 & 12.8 \\
Mean & 3.8 & 7.5 & 14.6 & 9.8 \\
\hline
\end{tabular}

Table 1c. Water quality of city effluent at site EIII (village name)

\begin{tabular}{lcccc}
\hline Month & $\begin{array}{l}\text { EC } \\
\left(\mathrm{d} \mathrm{Sm}^{-1}\right)\end{array}$ & pH & SAR & RSC \\
Nov 02 & 1.8 & 8.7 & 13.5 & 9.5 \\
Dec 03 & 2.1 & 8.3 & 16.6 & 9 \\
Jan 03 & 2.2 & 8.9 & 13.5 & 8.5 \\
Feb 03 & 2.8 & 8.4 & 18.8 & 9 \\
Mar03 & 2.1 & 9 & 19.5 & 11.5 \\
Apr 03 & 2.7 & 7.9 & 16.2 & 8.5 \\
May 03 & 3 & 8 & 22.5 & 14.8 \\
Jun 03 & 2.6 & 7.5 & 23 & 14 \\
July 03 & 2.4 & 7.4 & 17.2 & 8.7 \\
Aug 03 & 2.4 & 7.2 & 12 & 9 \\
Sep 03 & 2.8 & 7.3 & 18.9 & 11.2 \\
Oct 03 & 2.4 & 7.1 & 18 & 13.8 \\
Mean & 2.4 & 8.0 & 17.5 & 10.6 \\
\hline
\end{tabular}

Crop samples were collected randomly after the harvest of crop according to the selected points along the Hadiara drain and composited separately. The plant samples were washed with $1 \% \mathrm{HCI}$, followed by three to four washings with distilled water to 
remove the foreign material. Then spread on a clean paper and air-dried. The air-dried plant samples were oven dried at $60-70{ }^{0} \mathrm{C}$. Then oven-dried plant material was ground to powder form by Wiley mill ( $1 \mathrm{~mm}$ size) and will be stored in cleaned and dried plastic bags for chemical analysis.

\section{DISCUSSIONS}

Data on water quality at selected sampling points is shown at Table $1 \mathrm{a}, \mathrm{b} \& \mathrm{c}$ for electrical conductivity (EC), pH, Sodium Adsorption Ratio (SAR) and Residual Sodium Carbonate (RSC). Values for SAR and RSC are quite high as required by the standards by agriculture department Punjab and WAPDA criteria of water quality (11.9-17.5 and 6.7-10.6 respectively). The water of these values are not recommended for heavy irrigation due to its adverse chemical reaction in the soil because normal limits for SAR AND RSC are 10 and 2.5. Electrical Conductivity of the Hudiara Drain Water was also just above the normal values at point EI and it was higher at EII and EIII from the standards specified for crops irrigation (Ahmad and Chaudhry, 1997; Akhter,2000). Values of EC varies temporally at different places. $\mathrm{pH}$ of was found with in the normal range for the crops. It was also observed that at high temperature the crop showed some stunted growth. That was might be due to the excessive biodegradation and toxicity of the nutrients in the crop root zone.

Table 2. Metal ions in soil irrigated with city effluent at site EI

\begin{tabular}{llllll}
\hline Site & & $\mathrm{Cr}$ & $\mathrm{Zn}$ & $\mathrm{Pb}$ & $\mathrm{Fe}$ \\
$\mathrm{A}$ & $0-15$ & 0.08 & 2.3 & 2.1 & 425 \\
& $15-30$ & 0.08 & 1.5 & 2.1 & 523 \\
$\mathrm{~B}$ & $0-15$ & 0.12 & 3.5 & 3.2 & 245 \\
& $15-30$ & 010 & 2.2 & 3.5 & 124 \\
$\mathrm{C}$ & $0-15$ & 0.09 & 2.8 & 2.7 & 560 \\
& $15-30$ & 0.07 & 2.3 & 2.0 & 431 \\
$\mathrm{D}$ & $0-15$ & 0.23 & 4.5 & 2.5 & 520 \\
& $15-30$ & 0.15 & 1.9 & 1.5 & 410 \\
\hline
\end{tabular}

Table 3. Metal ions in soil irrigated with city effluent at site EII

\begin{tabular}{llllll}
\hline Site & & $\mathrm{Cr}$ & $\mathrm{Zn}$ & $\mathrm{Pb}$ & $\mathrm{Fe}$ \\
$\mathrm{A}$ & $0-15$ & 1.8 & 2.7 & 3.5 & 750 \\
& $15-30$ & 1.1 & 2.0 & 2.3 & 630 \\
$\mathrm{~B}$ & $0-15$ & 2.3 & 3.1 & 7.1 & 456 \\
& $15-30$ & 2.0 & 1.7 & 2.9 & 563 \\
$\mathrm{C}$ & $0-15$ & 0.8 & 1.9 & 5.2 & 450 \\
& $15-30$ & 0.6 & 1.9 & 1.4 & 396 \\
$\mathrm{D}$ & $0-15$ & 4.12 & 5.3 & 6.7 & 956 \\
& $15-30$ & 2.7 & 4.0 & 3.5 & 856 \\
\hline
\end{tabular}

Table 4. Metal ions in soil irrigated with city effluent at site EIII

\begin{tabular}{lllllc}
\hline Site & & $\mathrm{Cr}$ & $\mathrm{Zn}$ & $\mathrm{Pb}$ & $\mathrm{Fe}$ \\
$\mathrm{A}$ & $0-15$ & 4.3 & 3.2 & 8.4 & 1596 \\
& $15-30$ & 2.7 & 1.8 & 5.7 & 1235 \\
$\mathrm{~B}$ & $0-15$ & 8.4 & 4.5 & 6.4 & 780 \\
& $15-30$ & 7.1 & 3.0 & 3.4 & 678 \\
$\mathrm{C}$ & $0-15$ & 13.4 & 5.6 & 9.9 & 1166 \\
& $15-30$ & 7.4 & 3.7 & 7.7 & 803 \\
\hline
\end{tabular}

\begin{tabular}{llcccc}
\hline $\mathrm{D}$ & $0-15$ & 12.3 & 5.2 & 10.8 & 1400 \\
& $15-30$ & 7.4 & 3.0 & 7.1 & 923 \\
Mean & & 7.9 & 3.7 & 7.4 & 1072.6 \\
\hline
\end{tabular}

The water of drain at one side contain some nutrients like nitrogen, phosphorus, potassium and some secondary nutrients which enhance the fertility of the soil and increase the crop yield irrigated with the water of Hudiara Drain. But at the same time this water contain some heavy metal greater than their amount required by the crops sown with this polluted and fertile water. These heavy metals include Chromium (Cr), Lead ( $\mathrm{Pb})$, Zinc ( $\mathrm{Zn})$ and Iron $(\mathrm{Fe})$. While analyzing the heavy metal values in the soil it was found that at some cultivated area accumulation and availability of these elements are greater than required and specified limits. Values of chromium were found with in the normal range at EI while its values were higher at selected points EII and EIII. Similarly the values of $\mathrm{Pb}, \mathrm{Zn}$ and $\mathrm{Fe}$ were found higher at all the experimental sites than specified by the National Environmental Standards. The higher amount of these elements attributed to the long term practice of drainage water to these soils. Farmers have no supply of irrigation water and they are deliberately using this water due to its nutritive values and easy excess round the year.

Crop leaves were also analyzed for these heavy metals (Table 5-8) and values were found amazingly higher than the standard values $(\mathrm{Cr}(3.6-11.7 \mathrm{mg} / \mathrm{l})$, $\mathrm{Pb}(33.5-49.6 \mathrm{mg} / \mathrm{l}), \mathrm{Zn}(21.60-31.10 \mathrm{mg} / \mathrm{l})$ and $\mathrm{Fe}$ $(211.1-283.9 \mathrm{mg} / \mathrm{l})$ respectively. The higher values of these nutrients are toxic for human health and cause various disorder in the human body after the consumption of that contaminated food. Accumulations of these heavy metals are higher in vegetables than the other crops. This practice is very common at periphery of Lahore city. Higher values of these nutrients at selected sites EII and EIII are might be due to the toxic effluents of the textile, agrochemical, electroplating, food and leather industries. At down stream sites the large numbers of industries are throwing untreated water into the drains. Industries before EI ( Bedian Road Upstream) are not as higher as at remaining other points.

Table 5. Chromium concentration ( $\mathrm{ppm}$ ) in Spinach after irrigation with city effluent

\begin{tabular}{ccccc}
\hline Sites & EI & EII & EIII & Mean \\
A & 6.0 & 9.5 & 4.2 & 6.57 \\
B & 7.3 & 11.6 & 4.9 & 7.93 \\
C & 6.2 & 14.2 & 3.2 & 7.88 \\
D & 9.4 & 11.5 & 2.1 & 7.67 \\
Mean & 7.2 & 11.7 & 3.60 & 7.51 \\
\hline
\end{tabular}


Table 6. Zinc concentration (ppm) in Spinach after irrigation with city effluent

\begin{tabular}{ccccc}
\hline Sites & EI & EII & EIII & Mean \\
A & 23 & 35.5 & 21.4 & 26.63 \\
B & 22.4 & 41.7 & 29.2 & 31.10 \\
C & 27.3 & 23.7 & 13.8 & 21.60 \\
D & 18.7 & 45.2 & 19.6 & 27.83 \\
Mean & 22.9 & 36.5 & 21.0 & 26.8 \\
\hline
\end{tabular}

Table 7. Lead concentration (ppm) in Spinach after irrigation with city effluent

\begin{tabular}{ccccc}
\hline Sites & EI & EII & EIII & Mean \\
A & 19.2 & 87.2 & 28.3 & 44.9 \\
B & 22.3 & 105.4 & 21.2 & 49.6 \\
C & 13.4 & 70.2 & 16.8 & 33.5 \\
D & 27.1 & 73.4 & 20.3 & 40.3 \\
Mean & 20.5 & 84.1 & 21.7 & 42.1 \\
\hline
\end{tabular}

Table 8. Iron concentration ( $\mathrm{ppm}$ ) in Spinach after irrigation with city effluent

\begin{tabular}{ccccc}
\hline Sites & EI & EII & EIII & Mean \\
A & 195.5 & 257.3 & 180.7 & 211.1 \\
B & 277.4 & 362.3 & 212.2 & 283.9 \\
C & 314.3 & 220.7 & 250.6 & 261.8 \\
D & 165.2 & 290.3 & 185.2 & 213.5 \\
Mean & 238.1 & 282.6 & 207.2 & 242.6 \\
\hline
\end{tabular}

Conclusions: It is abstracted that the drain water contain heavy metal pollution along with high amount of SAR, RSC and Electrical conductivity. Moreover excessive use of this water is not only toxic for crops but also for soil health. On the basis of these results following recommendation are made for future sustainability of agriculture resources:

- Treatment of industrial water at point source is the best remedy for consumers. Industrialists should take this responsibility.

- Irrigation of drainage water should be followed by heavy irrigation to canal or groundwater of good quality.
- Government should ensure the canal water supplies for the farmers using this polluted water. And the industrialists play a key role in this participatory approach.

- Leafy vegetables should not be sown at this area.

\section{REFERENCES}

Ahmad. C.N. and M.R. Chaudhry. 1997. Review of Research on Reclamation of Salt-affected Soils in Pakistan. Internal. Waterlog. \& Salinity Res. Inst. (IWASRI). Lahore-Pakistan. $131 \mathrm{P}$.

Akhter, M. 2000. Remodeling of Punjab canals on the basis of flood flows. J. Pakistan Engineering Congress. 40 (19) : 13-24.

Davies, B. E. and L.H.P. Jones. 1989. Micronutrients and toxic elements. In : Wild A. (ed.). soil conditions and plant growth $\left(11^{\text {th }}\right.$ ed.). Longman Group, Burnt Mill, Harlow, UK.

Ghafoor, A., A. Rauf and W. Muzaffar. 1995. Irrigation with Madhuana drain water. Impacts on soils and vegetables ( spinach and cauliflower) at faisalahad. J. Drainage and Recl.7: 7-12.

Ghafoor, A., S. Ahmad, M. Qadir, S. I. Hussain and G. Murtaza. 1999. Formation and leaching of lead species from a sandy loam alluvial soil as related to $\mathrm{pH}$ and $\mathrm{Cl}$ : SO4 ratio of leachate. J. Int. Agri. Biol. 3: 82-84.

Ibrahim, M., N. Ahmad and S.A. Anwar. 1998. Sawage effluents and soil productivity. Intl. Seminar. In: Degraded Soils: Process, Management and Analysis. Oct. 19-24,1998. Univ. Agri., Faisalabad, Pakistan.

Kirkham, M. B. 1983. Study on accumulation of heavy metals in soils receiving sewage water. Agri. Eco system environ. 9: 251-255.

Misra, S. G. and D. Mani. 1991. Soil pollution. Ashish Publishing House, 8/81, Punjabi Bagh, New Delhi, India.

Richards, L.A. (ed). 1954. Diagnoses and Improvement of Saline and Alkali Soils. USDA Handbook No. 60, Washington, D.C.,USA.

Steel. R.G.D. and J.H. Torrie. 1980. Principles and Procedures of Statistics. McGraw Hill Book Co. N.Y., USA.

WAPDA (Water and Power Development Authority). 1993. Groundwater Quality in Punjab SCARP. Monitoring Report No. SM-141: 228 P. 